\title{
Issues of distance and proximity in neologisms, as instanced in e-commerce
}

John Humbley

\section{OpenEdition}

\section{Journals}

\section{Electronic version}

URL: http://journals.openedition.org/asp/325

DOI: $10.4000 / a s p .325$

ISBN: 978-2-8218-0406-7

ISSN: 2108-6354

\section{Publisher}

Groupe d'étude et de recherche en anglais de spécialité

\section{Printed version}

Date of publication: 1 November 2008

Number of pages: 25-38

ISSN: 1246-8185

\section{Electronic reference}

John Humbley, «Issues of distance and proximity in neologisms, as instanced in e-commerce », ASp [Online], 53-54 | 2008, Online since 01 November 2011, connection on 20 April 2019. URL : http:// journals.openedition.org/asp/325; DOI : 10.4000/asp.325

This text was automatically generated on 20 April 2019

Tous droits réservés 


\title{
Issues of distance and proximity in neologisms, as instanced in e- commerce
}

\author{
John Humbley
}

\section{The idea of distance and proximity in specialized neology}

1 Distance and proximity are parameters which may be usefully applied to analyzing how new terms come to be used, both in the language community where they originate and in those to which they are adapted. In the first case, we have examples of different professional communities coming together to create a new field of activity, and the resulting proximity facilitates not only transfer of ideas, but also of the words which express them. Once incorporated in the new community however, these terms will often gradually acquire new meanings, thus increasing distance from the original group. Use of in-group terms also tends to put distance between specialists or developers on the one hand and users on the other. The marketing people's major job is to reduce this distance and to find ways of building bridges to enhance linguistic proximity. When it comes to the second case, that of adapting terms developed in a different language community, there are several strategies available, which may also be expressed in terms of distance or proximity. For the specialists of the area, who are generally bilingual to some extent, the solution of proximity is to use the term in the original language, resulting in a loanword, or as direct a translation as possible. This scheme tends to put distance between specialists and those users who are not bilingual, so translators and those engaged in language planning prefer to switch the relationship and put distance between the original term and its equivalent in the adapting language, with a view to increasing proximity with the users, who can then more effectively incorporate the new terms in their active vocabulary. 


\section{Forming the terms of a new field: e-commerce}

\subsection{Appraising the neology of a terminology project}

2 To find out how these factors play out in an emerging field, I have gone over material gathered on the emergence of terms in an important branch of the New Economy: that of e-commerce. Much of this documentation was put together in preparation for the Vocabulary of E-commerce (Charette 2002), a project initiated by the network of Romance language terminologists, REALITER. The definition given for e-commerce in this Vocabulary is:

The buying and selling of information, products and services via the Internet.

3 The terms examined here will be restricted to those which actually figure in the published version of this dictionary, though attestations are also drawn from the preparatory corpus, and from the World Wide Web for evidence of developments before and after the period of the field work. A further reason for choosing the Vocabulary as a starting point is the methodological guarantee it offers, having been prepared initially by an international team of terminologists and thoroughly reworked by the Canadian Federal Translation Bureau, which is well known for its work in terminology, as displayed on its online tutorial, ${ }^{1}$ best known by the name of its author, Silvia Pavel.

The present study is therefore based on a secondary corpus, that of an existing dictionary, a methodology whose advantages and disadvantages should be briefly clarified. The advantage is to be able to cover a whole new field in a reasonable amount of time, and to benefit from the work of an international team working on term extraction in view to producing a dictionary of the terms specific to this new area. The main disadvantage is that the primary data is only available for inspection piecemeal, thus precluding independent validation. The results therefore give only directional and not statistical evidence, which may however be considered sufficient in terms of the aim of the paper, to study broad trends in the new terms of an emerging field.

5 As is well known, e-commerce was first developed in the United States as one of the principal manifestations of the New Economy, ${ }^{2}$ the conjunction of classical commerce enhanced by the new technologies of information and communication (IT). From this we can make a number of hypotheses about how new terms in this new and initially composite field will emerge. Firstly, it can be assumed that the matrix terminology will be that of business in general. Some of the terms will be expected to acquire more specialized meanings, thanks to the added value of IT. Other terms will come from IT itself, applied to business and marketing in particular, so once again more specialized meanings can be expected. The bulk of the specific new terms will then reflect the conjunction of the two fields.

\subsection{The basic vocabulary and its two parent fields}

6 These hypotheses are generally borne out by the evidence of the dictionary. E-commerce is part of commerce, so the terminology of commerce is used here, and much of it figures in the Vocabulary. The reader may however be surprised to find terms which appear to belong to commerce in general, and which are in no way specific to the new ways it is practiced on the web. Indeed, there is a considerable number of terms which would seem 
to be part of business terms included in the Vocabulary which at first blush would seem to have no particular connection to selling over the net, such as: "advertised item, business and customer protection, channel of distribution/distribution channel, purchasing pattern, unwary consumer, etc."

On closer inspection, it turns out that this may indeed be evidence of the beginnings of semantic specialization, minimal in most cases, but with a clear motivation. Some are explained by a definition in extension: for "channel of distribution/distribution channel, or purchasing pattern", for example, we now have to add to its distinctive features the Internet. Others have to do with new dimensions in this innovative form of commerce, notably in fields of security, as we shall see below. There were of course unwary customers before e-commerce was thought of, but the new medium increases the opportunities to defraud, so the possibilities of unwariness are also multiplied.

The main contributing field, the Internet and IT in general, is also represented in a similar way, though with rather fewer items: "open Internet; banner; (common) eplatform; Internet application; Internet infrastructure; pop-up page/popup page; portal; private communications network; proprietary network; screening device".

Again, the difference is in range of extension: "banner", for example, is used here in particular as an advertising banner; "pop-up page" is also seen as a marketing device, etc.

\subsection{Neology going back in time}

10 One group of new terms was not foreseen in the hypotheses and yet it is a typical lexical phenomenon when new concepts emerge. When this happens, new terms have to be found to refer to the old phenomena. Jacques Pohl (1993) calls this neology "going back in time" ('néologie à rebrousse-temps') and illustrates it in various sectors. In sailing for example, single-hull yachts have only been known by this expression since the inventions of catamarans made the distinction obligatory. It is therefore no surprise to learn that terms had to be found to refer to the older, non-e-commerce. Since the significant, defining difference of the latter was found to be its largely dematerialized form, it was only natural that the material aspect of traditional commerce should be highlighted. This was done by an expression of colloquial English "bricks and mortar", used metonymically to refer to anything solid or material, which spawned a number of expressions which have acquired the status of terms, and rate as headwords in the dictionary: "brick-andmortar buying/purchase, brick-and-mortar location, brick-and-mortar retailing, etc."

11 Paronymic attraction was sufficient to trigger an antonym in the form of "click-andmortar" to designate e-commerce, and is represented in the Vocabulary by "click-andmortar store".

12 The second surprise was the difficulty in distinguishing between e-commerce and its immediate predecessors, in particular distance payment and distance security. Clearly, proximity in these domains has led to a significant overlapping of terminology.

\subsection{The terminology of the immediate predecessor}

13 The Vocabulary includes the following terms designating distance payment, which predate e-commerce as such, but which are at the same time an integral part of the new field: 
cashless/electronic transaction; paperless transaction; digital cash/digicash/ ecash/electronic cash/e-money/electronic money; electronic funds transfer, electronic payment mechanism; worldwide financial transfer; point of sale terminal/POS terminal/retail point of sale terminal; privacy at point of sales terminal; privacy statement; Open-EDI

The last item, "Open-EDI" is a good example of preliminary language regulatory work (Blanchon 1993), since the very principle of Electronic Data Interchange (EDI) is a predefined, unambiguous set of denominations aimed at facilitating business exchanges.

The second great prerequisite to e-commerce, increased security measures and in particular an increased use of cryptography, is mirrored in many terms which are also henceforth considered part of the new field:

authentification, authentification certificate, authenticity, authorized user; 128-bit secure environment (e-commerce); Canadian Cryptography Policy; certificate/ certification authority; clarity of the code; character-coded information; code wording; cryptography; encryption (technology); entity authorization; entity identification; information privacy; level of protection/protection level; PIN security; Public Key Infrastructure/PKI; privacy/protection of personal information; personal information protection/privacy protection; private key; level of protection/protection level; public key; secure/secured; secured server

\subsection{The vocabulary of disintermediation}

The vocabulary of e-commerce proper may be held to begin with that of disintermediation itself. "Disintermediation" is a headword in the Vocabulary, and the definition stresses the elimination of as many intermediaries as possible, the defining feature of e-commerce. It is also part of the vocabulary of the New Economy, and included in the Encyclopedia of the New Economy. ${ }^{3}$ The elimination of the middleman, referred to in the gloss, led to a series of terms defining quite specifically which commercial partners are involved in particular business relationships, giving the series:

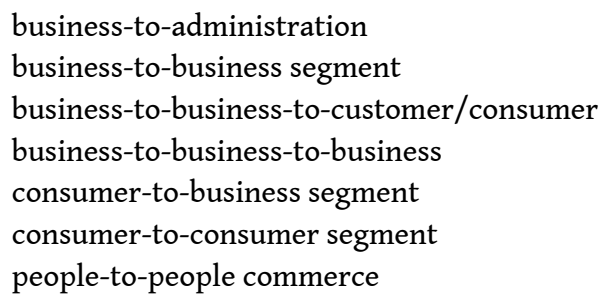

Once again, the list above is composed of those terms of the series which figure in the Vocabulary; further terms of the same series are also in current use, often without reference to e-commerce, such as "layperson to layperson".

The success of this paradigm was guaranteed by the acronyms developed from the individual terms on the $\mathrm{B} 2 \mathrm{C}$ ("business-to-customer") model, ${ }^{4}$ giving the corresponding series $\mathrm{B} 2 \mathrm{~A}, \mathrm{~B} 2 \mathrm{~B}, \mathrm{~B} 2 \mathrm{~B} 2 \mathrm{C}, \mathrm{B} 2 \mathrm{~B} 2 \mathrm{~B}, \mathrm{C} 2 \mathrm{~B}, \mathrm{C} 2 \mathrm{C}, \mathrm{P} 2 \mathrm{P}$, to limit the list to those terms included in the Vocabulary. Clearly, proximity with the user is achieved with this succinct yet precise means of reference. But how did this series of terms originate? It turns out that the model for the expression goes back to the jargon of the IT developers, who already used this sort of anarchistic abbreviation in the course of their own work. The following extract from a 1995 report, published in Java Rules, gives a good indication of how the term jumped from IT to business. 
This article examines both types of rules, deductive and reactive, shows when and how to apply them, and explains how rules can work together to provide a more effective semantic integration solution. It also examines the different uses of rules and applies rule technology to J2ME for desktop applications and J2EE for enterprise applications. This article looks at the use of rules for managing personal workflow, business transactions, and Web content in J2ME, J2EE, and JSP environments, respectively. It also covers the application of rules to B2B, customer relationship management (CRM), and supply chain management (SCM) applications. <http://www2.sys-con.com/ITSG/virtualcd/java/archives/0609/ross/ index. html>

19 The already established "in-house" terms in the short extract, J2ME, J2EE and JSP correspond to "Java to Micro Edition, Java to Enterprise Edition, Java Server Pages" respectively. The use of $\mathrm{B} 2 \mathrm{~B}$ without explanation suggests that it was already current in this context of software development, whereas SCM was either an innovation the time or not known to the IT workers involved in this project. This cross-over indicates the importance of the proximity of the communities of IT developers and the business community in the development of new terms. Its continued popularity is probably boosted by other occurrences of similar sorts of abbreviations, used in particular for text messages.

\subsection{Specific e-commerce terms: the basic matrix}

The dominant model for the specific vocabulary of this new field has been developed on the model of the generic term itself: "e-commerce". The determiner refers to a particular aspect of IT, and the qualified noun is the term used in traditional business. The Vocabulary lists eighteen of these qualifiers, with varying degrees of generality and metonymy. These are presented in figure 1, together with the nouns they qualify, as are listed in the Vocabulary. The most general determiner is "Internet", and other partial references such as web, "online", which can be considered as metonymies, as are most clearly "digital", "cyber", "electronic" and the clipping "e-. dotcom" (in its various spellings) is a different kind of metonymy, homing in not on a part of the system itself, but on the name of its representatives, i.e., those companies with a website address incorporated into the name.

Figure 1. The dominant matrix producing the terminology of e-commerce

\begin{tabular}{|l|l|}
\hline IT determiner & Traditional business term \\
\hline $\begin{array}{l}\text { B2B, B2A, B2C, } \\
\text { etc. }\end{array}$ & commerce; application \\
\hline cyber & $\begin{array}{l}\text { bookstore; client; customer; entrepreneur; library; mall; market; marketplace; } \\
\text { merchant; PR; shopper; store; wallet }\end{array}$ \\
\hline digital & cash; certificate; certification; commerce; economy; service; signature \\
\hline $\begin{array}{l}\text { dotcom (dot- } \\
\text { com, .com })\end{array}$ & company, firm \\
\hline
\end{tabular}




\begin{tabular}{|c|c|}
\hline $\mathrm{E}$ & $\begin{array}{l}\text { business; business cluster; business front office solution; business solution; } \\
\text { cash; cash card, payment card; client; commerce; commerce solution; } \\
\text { customer; procurement solution; tailing; ticket; wallet; location; merchant; } \\
\text { money }\end{array}$ \\
\hline electronic & $\begin{array}{l}\text { bill presentation and payment (EBPP); business; business cluster; cash; } \\
\text { commerce; commerce platform (ECP); data exchange; funds transfer; money; } \\
\text { data interchange; delivery; funds transfer; megastore; payment mechanism; } \\
\text { procurement solution; signature; signature recognition; recognition of } \\
\text { signatures; store; tailing [sic]; ticket; transfer; wholesale trade }\end{array}$ \\
\hline intelligent & shopping agent \\
\hline interactive & advertising; kiosk; media firm; storefront; terminal \\
\hline Internet & $\begin{array}{l}\text { advertiser; application; auction; cluster; economy; infrastructure; location; } \\
\text { reverse auction; value chain }\end{array}$ \\
\hline $\begin{array}{l}\text { information } \\
\text { Technology } \\
\text { (IT) }\end{array}$ & enablement \\
\hline mobile (m) & commerce \\
\hline net & economy; entrepreneur \\
\hline new & economy \\
\hline online & $\begin{array}{l}\text { advertising; auction; authorization; billing; invoicing; bookstore; buyer; } \\
\text { catalogue; client; consumption; customer; exchange; intermediary; library; } \\
\text { mall; market; marketplace; megastore; merchant; procurement solution; } \\
\text { purchase; retailing; sale; services; shopper; shopping; shopping assistant; } \\
\text { trading venue; transaction }\end{array}$ \\
\hline pure Internet & business \\
\hline robo & shop \\
\hline virtual & location; mall; megastore; store; transaction \\
\hline web & bookstore; business information network: economics; (Webonomics); shopper \\
\hline
\end{tabular}

21 With over one hundred and twenty terms, this model represents the dominant neology matrix of the Vocabulary, precisely the model which highlights the proximity between the two parent fields. It is a particularly felicitous solution, as the determiner can be dispensed with as e-commerce becomes the default mode of doing business, as France Lafargue, the major adaptor of EDI to French, foresaw in $2002 .{ }^{5} \mathrm{Her}$ prediction that the IT determiner would fall by the wayside when most commerce became e-commerce is borne out by The Economist: The World in 2008 "Any manager who says 'clicks and mortar' or 'disintermediation' in 2008 should be preserved and kept for posterity". (The Economist 2008: 134) 


\subsection{Specific e-commerce terms: other matrices} initialisms or as blends. ${ }^{6}$ The success of the alphanumeric series B2C has already been commented on, and other initialisms from related domains, such as security, are common. Splinters, or truncation of lexical morphemes, are also represented in two main forms; joined together, they form blends or portmanteau words. The first and most prominent is the series started in the IT field by abbreviating "electronic to e-", and is represented by no less than eighteen terms forms (many of which are synonyms, however) in the Vocabulary alone. of this series, all keep to the model of a truncated form for the first element (e-) but an untruncated form for the second, bar one: "e-tailing or online retailing". The explanation is the usual blend motivation of a common pivot, here the spoken vowel [i:]. It is strange however to also find the form "electronic tailing" in the Vocabulary, which by 2007 had to all intents and purposes disappeared from the web. Its more recent variant "i-" (as in "i-pod") was not yet current when the fieldwork was done, but " $\mathrm{m}-$ " " for "mobile" was. It is represented by " $\mathrm{m}$-commerce", and many more recent terms. The other form of blends is more usual in that the reduction is less radical, but they are relatively isolated and not only do not constitute a paradigm, but tend to fade away. The Vocabulary includes "digicash" ("digital cash", where only the first element is a splinter), "Webonomics" (only "economics" here is a splinter), which bears uncomfortable resemblance to "Reagonomics", and "vortal," a classical blend of "vertical portal," whose demise was gleefully greeted by The Economist at the beginning of 2008. ${ }^{8}$ Use of initialisms saves time for the in-group, but can put distance between specialist and non specialist. Blends are often easier to reconstitute from their component parts, and for this reason are recommended by various specialists, including Eugen Wüster (1979), and, closer to us, Jacqueline Percebois (forthcoming).

The first hypothesis, that the majority of new terms in e-commerce is thus borne out by the evidence provided in the Vocabulary, with most of the new terms being constructed according to a small number of models, the main one qualifying traditional commercial practices or with an IT dimension. This unusually open means of terminology expansion should facilitate both specialists and the general public. 


\section{Adapting the vocabulary of e-commerce to French}

Adapting the English terminology to French has proved relatively straightforward, in comparison with many other more complex emerging fields, such as IT itself, thanks to the fairly simple form of syntagmatic term formation as illustrated above. To take the terms (all from the Vocabulary, as specified in the Introduction) in the order they were reviewed in English, it is to be expected that for the terms of conventional commerce which acquire added meaning in their new context will already be part of French commercial terminology, and in many cases this is indeed the case: "channel of distribution" - canal de distribution; "purchasing pattern" - profil d'achat, etc. In some cases however, distinctive paradigms are formed in French, such as élément publicitaire, for "advertised item," reflecting bannière publicitaire or "advertising banner." Some of the expressions appear to be more fully lexicalized in English than French, such as the already mentioned "unwary consumer" (consommateur imprudent); this is also the case of "prominently displayed" (divulgue de manière évidente) and "trusted third party" (tierce de confiance, tierce partie de confiance)... In addition, even with expressions which have evolved very little from conventional business terminology, we find a large numbers of synonyms proposed in the French part of the Vocabulary: for "trusted," for example, de confiance, fiable, éprouvé, validé. The user is possibly not very much more enlightened by reading the "equivalent may vary according to context." Visibly basic business terminology is still to some extent culturally determined in French and English speaking communities, even in countries such as Canada.

Preexisting French terminology also contained an unexpected element: a number of terms coined independently of English before e-commerce took off in the area of electronic payment, pioneered by such French developers as Roland Moreno, the inventor of the smart card (carte à puce); monnaie électronique was well on the way to full development fifteen years before the publication of the Vocabulary (Dupas, Frèches 1987: 235), followed by public initiatives in France such as the electronic wallet Moneo (portemonnaie électronique). In addition, standardizing authorities, mainly AFNOR in France, played an important role in regulating this new field, and the language institutes such as the office (québécois) de la langue française and the Délégation générale à la langue française, not to mention the Canadian Translation Bureau have a long track record in this area. The resulting equivalents in French generally sound more roadworthy: transaction en ligne/électronique; monétique (rather than argent électronique, a direct loan from "electronic/e-money"), transfert électronique de fonds (virement électronique), terminal de point de vente, politique de confidentialité (for "privacy statement"). In addition, EDI was transposed into French in the 1990s under the direction of France Lafargue (Blanchon 1993), giving a firm basis for further term development.

Terms taken from IT are stabilized in French: interconnexion, interopérabilité de l'infrastructure de l'information, etc.), in particular for vocabulary of the Internet: réseau ouvert, Internet ouvert, bannière publicitaire, applications internet, infrastructure internet, réseau, though in this section there is some evidence of a lexicographical push to more distant equivalents to preserve the integrity of French. For proprietary network the equivalent given is réseau exclusif, although réseau propriétaire, favoured by the professionals, is not mentioned. Similarly, page intersticielle for "pop-up (page)" would 
seem to be at once a valiant effort and a forlorn hope, since the direct loan is found in almost all contexts.

For the paradigm of the players of disintermediation, the Vocabulary favours translation rather than use of the English initialism. Two main strategies are pursued here: either using an analytical form, similar to the English model, giving for example commerce de personne à personne for "person to person" (P2P) or commerce entre enterprises for "business to business commerce" (B2B) or using a synthetic form with inter-: interentreprise for the latter, interpartenaires for B2B2B. In order to compare the uptake of these equivalents a quick Google search performed on $8^{\text {th }}$ January 2008 gave the results summarized in figure 2. In order to restrict the documents to French writing on e-commerce, only Frenchlanguage pages were requested, and as was the presence of "commerce électronique". This last requirement probably resulted in the very low count in most cases.

Figure 2. Relative frequencies of French equivalents of the vocabulary of disintermediation

\begin{tabular}{|c|c|c|c|c|c|}
\hline & Frequency & & Frequency & inter- & Frequency \\
\hline B2A & 558 & $\begin{array}{l}\text { entreprise- } \\
\text { administration }\end{array}$ & 10 & & \\
\hline B2B & 34,000 & entre entreprises & 12,200 & interentreprise & 12,700 \\
\hline B2B2C & 595 & & & $\begin{array}{l}\text { interpartenaires } \\
\text { orienté client }\end{array}$ & 0 \\
\hline B2B2B & 152 & & & interpartenaires & 4 \\
\hline B2C & 12,400 & $\begin{array}{l}\text { commerce avec les } \\
\text { consommateurs } \\
\text { commerce électronique } \\
\text { de détail } \\
\text { commerce de détail } \\
\text { CED* } \\
\text { Commerce grand public }\end{array}$ & $\begin{array}{l}453 \\
4,460 \\
1,060 \\
632 \\
597\end{array}$ & & \\
\hline $\mathrm{C} 2 \mathrm{~B}$ & 501 & $\begin{array}{l}\text { consommateur- } \\
\text { entreprise, } \\
\text { consommateur- } \\
\text { marchand }\end{array}$ & $\begin{array}{l}94 \\
38\end{array}$ & & \\
\hline $\mathrm{C} 2 \mathrm{C}$ & 2,210 & & & interconsommateurs & 87 \\
\hline P2P & $39,500 * *$ & $\begin{array}{l}\text { (commerce) de personne } \\
\text { à personne }\end{array}$ & 1,840 & & \\
\hline
\end{tabular}

* Much noise: Canadian Export Development Inc. (CED); PARIS LA DEFENSE CED; Centre d'éducation à distance (CED), etc.

** Many P2P would be peer to peer, even in an e-commerce setting. 
The results are very much rough and ready, but do confirm the preference of Frenchlanguage users for the borrowed initialisms, which in all cases are more common than any of the equivalents. Some of the proposals do reach respectable scores, however, such as entre entreprises and interentreprise, so it would be greatly exaggerated to declare these distant equivalents so many dead letters. It is interesting to note a good representation of commerce de détail, bearing out France Lafargue's prediction for French as well as English.

31 The main formula for making new terms in English, a term from conventional business vocabulary qualified by an indication of the new technologies which make the change possible, is easily transferred into French, thanks to proximity of structure. The closest correspondence is the series starting with cyber-, as this pseudo-classical element is also used in French, and has the advantage of keeping the same order of elements. Charette (2002: iv) commends these forms in particular ("Of special interest is the innovative and creative nomenclature, especially French equivalents such as cyberthèque, a synonym for cyberbibliothèque...").

Figure 3. French equivalents including cyber-

\begin{tabular}{|l|l|}
\hline English & French \\
\hline cyberbookstore & cyberlibrairie \\
\hline cyberclient, cybercustomer & cyberclient/client en ligne \\
\hline cyberentrepreneur & cyberentrepreneur \\
\hline cyberlibrary & cyberbibliothèque, cyberthèque, bibliothèque en ligne \\
\hline cybermall & cybercentre commercial, centre commercial en ligne \\
\hline cybermarket, cybermarketplace & cybermarché, marché en ligne \\
\hline cybermerchant & cybermarchand, marchand en ligne \\
\hline cyber PR & cyber-RP \\
\hline cybershopper & cyberacheteur, acheteur en ligne \\
\hline cyberstore & cyberboutique, boutique électronique, magasin électronique \\
\hline cyberwallet & porte-monnaie/portefeuille électronique \\
\hline
\end{tabular}

Other equivalents which contain an adjective are also transferred into French without difficulty, though the order of elements changes, thereby somewhat reducing proximity.

Figure 4. Examples of French equivalents involving an adjective

\begin{tabular}{|l|l|}
\hline English & French \\
\hline
\end{tabular}




\begin{tabular}{|l|l|}
\hline $\begin{array}{l}\text { interactive } \\
\text { advertising }\end{array}$ & publicité interactive, publicité en ligne \\
\hline virtual location & $\begin{array}{l}\text { emplacement virtuel, emplacement sur Internet, emplacement } \\
\text { électronique }\end{array}$ \\
\hline electronic commerce & commerce électronique \\
\hline digital signature & signature numérique, signature électronique \\
\hline
\end{tabular}

A number of English constructions involving two nouns are also given in French simply by reversing the order: "Internet value chain" - chaîne de valeur Internet (but a linking preposition is usually added: "Internet advertiser" - publicitaire sur Internet), or a prepositional construction: "online buyer" - acheteur en ligne, acheteur électronique, cyberacheteur. Charette himself admits that

French usage is somewhat vague for such adjectives as en ligne, électronique and virtuel and follows no specific guidelines. Indeed, standardization authorities have not yet established rules for their use. (Charette 2002: iv)

The most distant equivalent proposed in the Vocabulary is for the splinter $e^{-}$, which has no close equivalent in French. The Vocabulary suggests full forms, with électronique or numérique (signature électronique, signature numérique) or cyber-, the latter preserving the order of the elements, as in cyberboutique, for "e-shop". In a bilingual environment, the distance between the two solutions puts French at a comparative disadvantage, since the equivalents are invariably longer than the English, sometimes by several syllables. It should be noted that this phenomenon is not confined to the field of e-commerce: in that of education, for example, the loanword "e-learning" is also more common in French texts than any other equivalent. The solution of using the splinter "-el," inaugurated to render "e-mail" (courriel, a blend of courrier + électronique), was recently suggested for "electronic book" (livrel), ${ }^{9}$ but came too late to be included in the Vocabulary.

\section{Conclusion}

This brief review of most of the new terms associated with e-commerce included in a recent terminological publication confirms that the notions of distance and proximity are relevant to obtaining a better understanding of how new terms are formed and how they circulate. Proximity of professional groups is necessary to introduce new terms, as the technological developments which paved the way for this new form of doing business introduced not only their vocabulary but also their preferred ways of coining terms.

When it comes to introducing new English-based terms into French there is a palpable tension between the tendency manifested by the professionals to maintain as much proximity as possible and that of the makers of the Vocabulary, who endeavour to strengthen the autonomy of French by proposing terms which conform to French usage, but at the price of increasing the distance between English and French equivalents. A cursory search on the web suggests that while the tendency towards increased proximity is dominant, a significant number of terms manifesting a certain distance from English have been accepted by usage. The next phase of the research will be to determine which usage prefers which equivalents. 


\section{BIBLIOGRAPHY}

Adams, Valerie. 1973. An Introduction to Modern English Word-Formation. London: Longman.

Blanchon, Elisabeth. 1993. "EDI : un défi pour la terminologie". La Banque des mots numéro spécial, 88-91.

Browning, John \& Spencer Reiss. 1999. The Encyclopedia of the New Economy, Wired.

Charette, Eric (ed.). 2002. "Vocabulaire du commerce électronique/Vocabulary of E-commerce". Public Works and Government Services, Canada, Terminology Bulletin 250.

Percebois, Jacqueline. 2009. “Les procédés d'économie linguistique : quels partenaires pour la communication ?". In Greenstein, Rosalind (ed.). Langue et culture - mariage de raison ? Paris : Publications de la Sorbonne, 17-43.

Pohl, Jacques \& Martine Coutier. 1993. "Néologie à rebrousse-temps". Cahiers de lexicologie 63, 99-112.

Wüster, Eugen. [1979] 1985. Einführung in die allgemeine Terminologielehre und terminologische Lexikographie. Vienna, Copenhagen: Infoterm, Handelshøjskolen i København.

\section{NOTES}

1. <http://www.termium.gc.ca/didacticiel_tutorial/francais/lecon1/indexe_f.html>.

2. The Encyclopedia of the New Economy (Browning \& Reiss 1999) explains the term: "Doing business on the network. More and more companies are making the Web their storefront. It's cheap, global, and quick, with no margin-sapping middlemen."

3. The pithy definition given by the Encyclopedia, "Cutting out the middleman" is an indication that the incorporation of the term into e-commerce has added more specific features. The authors situate the beginning of disintermediation with the liberalization of stock markets, well before the development of e-commerce: "Disintermediation first gained momentum in financial markets when customers began forsaking savings banks for their stockbrokers' money market accounts - denying banks the opportunity to make a nice return by investing the funds in money markets themselves." (Browning \& Reiss 1999).

4. "English is equally creative having welcomed into the language such concepts as B2B (businessto-business), B2C (business-to-consumer) and B2B2B (business-to-business-to-business) which are now familiar to us. These terms are very concise, clear, well suited to e-commerce and used by those who work in this field". (Charette 2002: iv)

5. "Pour ma part, j'ajouterai dans le domaine du 'commerce', les prestataires de service (banquiers, douaniers, transporteurs, assureurs...). C'est une excellente idée que de prendre le 'commerce électronique' comme thème de projet. Mais je pense qu'à terme le commerce électronique deviendra la seule façon de commercer et le qualificatif 'électronique' disparaîtra naturellement." (France Lafargue, Afnor, personal communication, 2002).

6. The terminology used here is that of Adams (1973).

7. "-onomics" is becoming available as a splinter, as evidenced by more than sporadic occurrences of "Clintonomics" and "Bushonomics" in the American press. 
8. "Vortal", a word for an industry web portal, had a mercifully short lifespan (The Economist: The World in 2008: 134)

9. Notably by the Office québécois de la langue française. < http://www.olf.gouv.qc.ca/ RESSOURCES/bibliotheque/dictionnaires/Internet/fiches/8375423.html>.

\section{ABSTRACTS}

Distance and proximity are useful parameters for studying the emergence of new terms. Firstly the coming together of specialists from different fields generates a stock of new terms to express the new techniques and activities which result. Secondly, when these terms are transferred to other language communities, there is a tension between the specialists and translators. The area chosen to investigate the issues of distance and proximity in coining new terms is e-commerce. The basic matrix for new terms turns out to be commerce itself, qualified by various contributions from information technology, demonstrated here in detail for the sub-field of disintermediation. The proposed equivalents in French are then studied, using a glossary published by the Canadian Federal Translation Bureau. The terms which are most distant from the English originals are rarely taken up whereas those which are closer are readily attested. More independent term forms are found in areas developed independently in French, such as money transfer.

La notion de proximité et de distance peut être utile pour analyser l'émergence de termes nouveaux. D'une part, on peut étudier la rencontre de plusieurs disciplines ou secteurs qui concourt à la création de nouveaux domaines d'activité. D'autre part, lorsqu'il s'agit de traduire une terminologie élaborée dans une communauté linguistique donnée, on constate une tension entre l'attitude des professionnels et celle des traducteurs. Un corpus de termes représentatifs du commerce électronique est examiné à l'aide d'une typologie des formes privilégiées par l'anglais. La rencontre de deux secteurs se manifeste par la création de nouveaux termes sur le modèle du vocabulaire commercial. Ces termes de langue anglaise et les équivalents proposés par des traducteurs sont ensuite comparés. Il en ressort que les équivalents français les plus proches de l'anglais sont employés en pratique, tandis que ceux qui s'en éloignent finissent par être écartés par les utilisateurs, sauf dans le cas des domaines déjà constitués, comme celui de la monétique.

\section{INDEX}

Mots-clés: commerce électronique, communauté linguistique, emprunt, néologie

Keywords: borrowing, e-commerce, language community, neology

\section{AUTHOR}

\section{JOHN HUMBLEY}

John Humbley is a Professor in applied linguistics at UFR des Études interculturelles de langues appliquées of Université Paris-Diderot, where he teaches terminology and specialized translation. His research deals with terminology, neology and plurilinguism. In 2006 with Jean- 
François Sablayrolles, he created Neologica (LDI UMR 7181), a journal published by Éditions Garnier. humbley@eila.univ-paris-diderot.fr 